\title{
Origin of peloids in Early Cretaceous deposits, Dorset, South England
}

Received: 4 February 2005 / Accepted: 26 April 2005 / Published online: 2 September 2005

(C) Springer-Verlag 2005

\begin{abstract}
Peloids are ubiquitous components in modern and fossil carbonates. The term peloid is non-genetic because the origin of these grains and the pathways of their formation are not fully understood. Based on Berriasian material originating from Dorset, southern England, we report here on peloids that result from the more or less in-place breakdown of previously micritized bivalve shells. The continuum from shell breakdown to peloids is documented by petrography and observation by scanning electron microscopy. The identical elemental composition of peloids and micritized shells confirms the petrographic observation and interpretation. Bivalve shells that were previously entirely micritized appear to be the preferential source for the formation of peloids. Obviously, the micritization weakened the shells, facilitating their breakdown and abrasion. This result identifies the fragmentation of micritized shells as a process leading to the formation of distinct peloids, adding to the categories of peloids recognized to date. Mold, mud, and microbial peloids observed in the studied sections and documented herein are distinct from peloids derived from bivalve shells.
\end{abstract}

Keywords Peloids $\cdot$ Micritization $\cdot$ Diagenesis $\cdot$ Early Cretaceous · Dorset

\section{Introduction and methods}

Peloids are small, rounded, spherical to ellipsoidal, cryptocrystalline carbonate aggregates commonly lacking internal structures. These aggregates generally vary in size from 30 to $100 \mu \mathrm{m}$ and rarely exceed $500 \mu \mathrm{m}$

E. Samankassou $(\bowtie) \cdot$ J. Tresch $\cdot$ A. Strasser Department of Geosciences, University of Fribourg,

Pérolles, CH-1700 Fribourg, Switzerland

e-mail: elias.samankassou@unifr.ch

Tel.: +41-26-300-89-76

Fax: +41-26-300-97-42
(Fahraeus et al. 1974; Bathurst 1975; Flügel 2004). As originally defined by McKee and Gutschick (1969), the term is purely descriptive. The origin of peloids is not fully understood, although they are ubiquitous components in modern and fossil carbonates (Illing 1954; Stieglitz 1972), and different peloid types were described. Attempts of classification are hampered by doubts on the genesis of these grains (e.g., Wilson 1965), mirrored in the common expression "peloids: just a term of ignorance?" (e.g., Scholle and Ulmer-Scholle 2003; Flügel 2004).

Macintyre (1985) grouped peloids into three categories according to their origin: fecal, detrital, and in situ precipitated. Based on the probable origin and diagnostic criteria, Flügel (2004) proposed nine subcategories: fecal pellets originating from organic excrements; algal peloids resulting from the abrasion of algae and calcimicrobes; bioerosional peloids resulting from boring and rasping by organisms; mud peloids as products of reworked cohesive mud; mold peloids resulting from internal molds of fossils; Bahamite peloids and pelletoids resulting from the alteration of grains; microbial and precipitated peloids, both formed in situ biochemically and chemically, respectively.

Here we report on peloids that result from the more or less in-place breakdown of previously micritized bivalve shells, adding to the category of detrital peloids recognized to date. We not only focus on peloids resulting from this process but also document examples of other peloid types observed in the same sections. The study is based on petrography of thin sections, observation by scanning electron microscopy (SEM), and determination of elemental composition by energy-dispersive spectroscopy (EDS), using an in-house Focused Electrons and Ions XL 30 Sirion FEG. The Berriasian material studied originates from sections measured in Dorset, southern England. The results presented are qualitative. The distribution of different peloid types and their possible link to environmental changes will be the focus of a subsequent paper. 
Fig. 1 Geographic location of the measured sections in Dorset, southern England

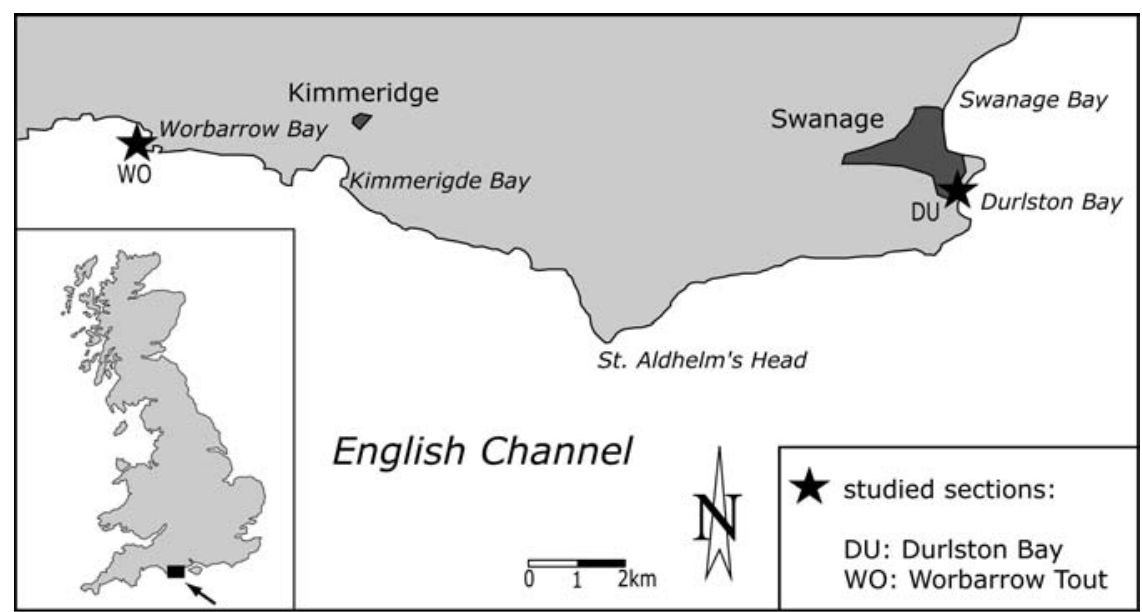

\section{Site of the study}

\section{Location}

The two measured sections relevant for the study are located in Dorset, southern England, on the coast of the English Channel (Fig. 1): The Durlston Bay section south of the seaside town of Swanage at the eastern end of the Isle of Purbeck (Clements 1993); and the Worbarrow Tout section on the western side of Worbarrow Tout, a small peninsula at Worbarrow Bay (Ensom 1985).

\section{Stratigraphy}

The sections are dated by ostracodes (e.g., Anderson 1985). The ca. 3-m thick, oyster-rich Cinder Member serves as a major correlation level. It is located in the runctoniammonite zone of the Middle Berriasian (Norris 1985).

Both sections were well described lithologically and subdivided into formations and members in previous studies (e.g., Ensom 1985; Clements 1993). The correlation is mainly based on lithological criteria.

\section{Measured sections}

The two measured sections (WO and DU; Fig. 2) consist of grayish-beige bedded mudstone, wackestone, and packstone. Beds are organized in bundles punctuated by gray to black marls or a bituminous layer. The fossil content includes multiple bivalves (Chlamys sp., Praeexogyra distorta, Neomiodon cf. medius, Corbula sp.), gastropods (Viviparus sp., Hydrobia sp.), ostracodes (Cypridea sp., Darwinula sp.), and charophytes (Milner and Batten 2002). The biotic assemblages point to lacustrine to shallow-lagoonal depositional environments (Milner and Batten 2002) and, accordingly, to variations through time in salinity ranging from freshwater and brackish to marine conditions.

\section{Petrographic and SEM data}

Shell morphology and micritization processes

Different preservation degrees of bivalve shells occur in the material studied. Whereas some shells have their lamellar and prismatic microstructures preserved, others are entirely micritized (Fig. 3). Transition stages from partially to entirely micritized parts of the same shell fragment suggest that most of the totally micritized bioclasts originate from bivalve shells (Fig. 3B and $\mathrm{C}$ ). The random micritization within the same shell points to a process that is not exclusively dependent on the shell microstructure and mineralogy (for the mechanism of aragonite neomorphism in mollusk shells, see Maliva and Dickson 1992).

Micritization processes are known to be manifold, resulting from various mechanisms that have been proposed in previous studies. While some workers suggested boring by bacteria and subsequent micritic infilling as the dominant process (e.g., Bathurst 1966), others proposed that recrystallization might equally account for producing similar results (cf. Reid et al. 1992). Both mechanisms may account for the micritization seen in the Dorset material, but infillings of tubes in obviously bored shells is the mechanism that can be well documented (Figs. 3C and 4).

\section{Peloid types}

Type 1: Peloids are round to sub-rounded. The diameter ranges from 60 to $300 \mu \mathrm{m}$, with an average of $130 \mu \mathrm{m}$ and a median value of $120 \mu \mathrm{m}$ (based on 60 particles). These dimensions lie within the higher values of ranges given in the literature (see Flügel 1982, 2004). The contours are smooth. Peloids lack internal structures that can be identified as relict structures of fossils, even at high resolution (Fig. 5C).

Type 1 peloids co-occur with multiple micritized bivalve shells (Fig. 5A). Different degrees of shell micritization are observed, including partially, superficially, or entirely micritized shells. The transition can occur within the same 


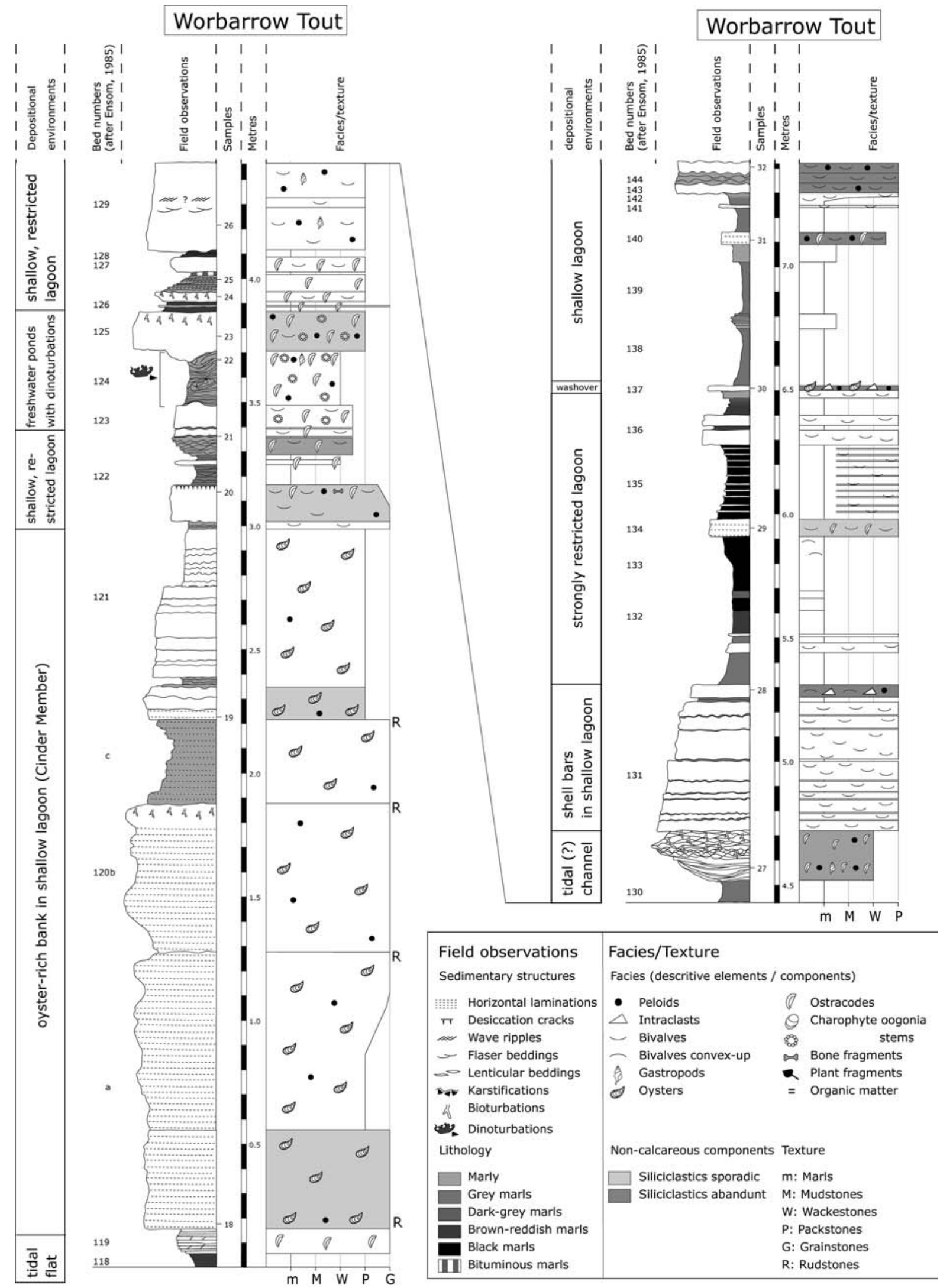

Fig. 2 Partial logs of the measured sections. Bed numbers for Worbarrow Tout refer to those used by Ensom (1985), and for Durlston Bay to those by Clements (1993) 


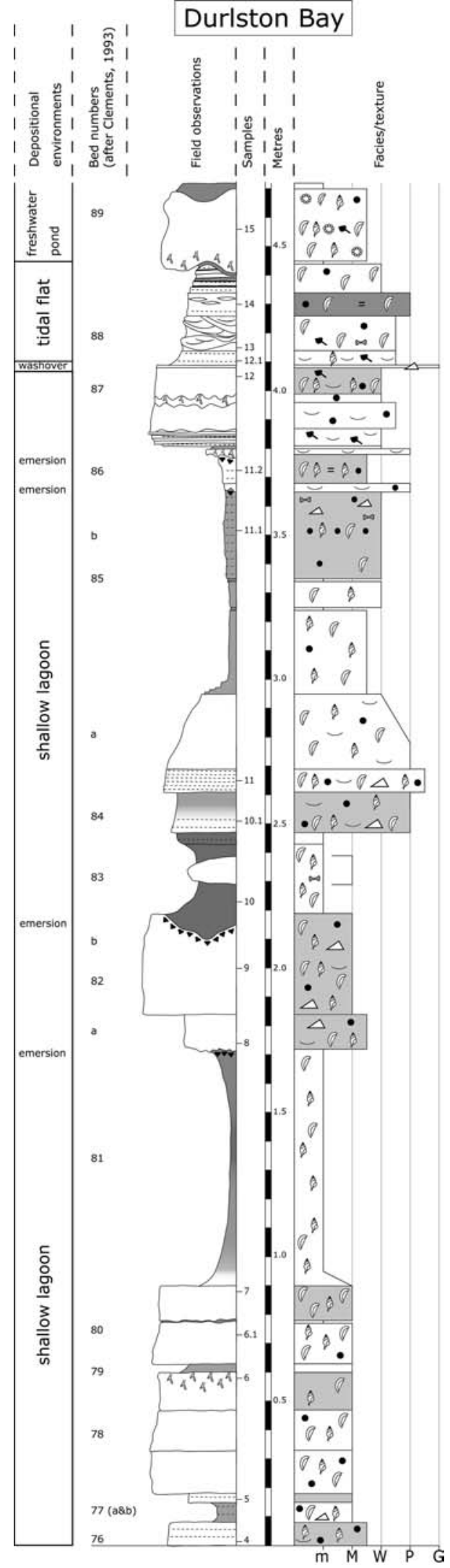

Fig. 2 Continued shell (Figs. 6 and 7). Interestingly, thin sections having the highest amount of micritized shells are also rich in peloids. Most importantly, different stages in the breakdown of micritized shells occur. Some micritized shells are intact, while others are partially disintegrated. In the latter, broken particles (proto-peloids) are still close to the shells from which they are derived (Fig. 8). Subsequently, the proto-peloids become isolated and develop into type 1 peloids.

We did not recognize other rounded grains comparable in size and composition to those of type 1 peloids. Whereas shells exhibiting micritic envelopes may be broken, resulting in small, millimeter-sized, elongated grains that are larger than peloids of type 1 , no small grains were observed in thin sections composed of shells without micritic envelopes (Fig. 9A and B). The latter tend to dissolve.

Type 2: In a few thin sections, peloids showing relics of fossils occur. Fragments of thin-shelled ostracodes are the dominant components in such peloids (Fig. 9C). Overall, the contours of such peloids mimic the morphology of the ostracode valves. Multiple areas in the thin sections show clasts of mudstone including ostracodes, obviously the source material of type 2 peloids. If the ostracode valves dissolve, such peloids may develop into the mold peloids of Flügel (2004).

Type 3: Mud peloids occur in a few samples from the Durlston Bay section. They are overall larger than the type 1 peloids $(>500 \mu \mathrm{m})$. Such peloids co-occur with muddy aggregate grains; the continuum and transition from aggregates to peloids is conspicuous (Fig. 9D), permitting to unambiguously distinguish mud peloids from those derived from micritized bivalve shells (the type 1 described earlier). In a few thin sections, mud peloids are not uniform in composition as their source material. As mud peloids lack ostracode shells and other skeletal grains, they can be distinguished from the type 2 describe earlier.

Type 4: In a few thin sections, peloids occur in clusters (Fig. 10). Such peloids are basically limited to intraparticle pores (preferentially of ostracodes and gastropods). They are smaller than all other types described earlier $(<50 \mu \mathrm{m})$. Their fuzzy outlines and the occurrence in clusters point to a microbial origin, in analogy to the interpretation of clotted peloids reported throughout the Phanerozoic (e.g., Macintyre 1985; Chafetz 1986; Riding 2000).

\section{Elemental composition (EDS data)}

Peloid types 2, 3, and 4 are well documented in previous studies (see discussion later). Therefore, the EDS analysis was limited to peloid type 1, the focus of the present study. Polished slabs were analyzed using SEM; the elemental distribution (maps of selected areas) was analyzed using EDS that allowed characterization of the composition of the various components.

Shells and peloids are impoverished in $\mathrm{Al}, \mathrm{Fe}, \mathrm{Si}, \mathrm{K}$, and $\mathrm{Sr}$, unlike the matrix that is enriched in these elements (Fig. 11). The distribution patterns rule out the matrix as source for peloids ascribed to type 1 . The compositional 


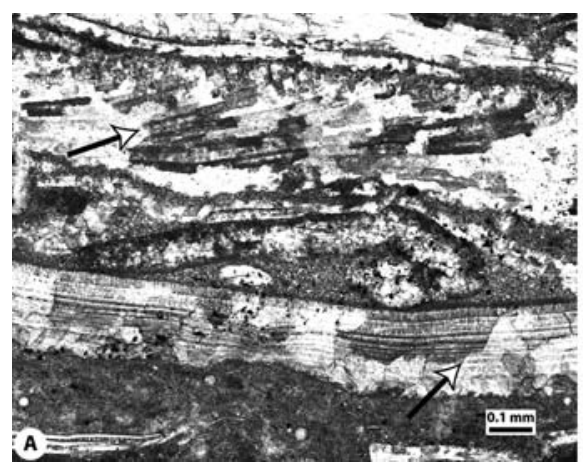

Fig. 3 Shell microstructures: (A) Non-micritized shells with partly preserved lamellar (upper arrow) and prismatic (lower arrow) microstructures. The neomorphism affects both the lamellar and the prismatic layers (well visible in the lower shell, right to the arrow). See Maliva and Dickson (1992) for details on mechanism of mollusk-shell neomorphism. Sample \#WO 30. (B) Different stages in the micritization of shells. Relics of primary prismatic (upper arrow) and lamellar (lower arrow) shell layers are visible.

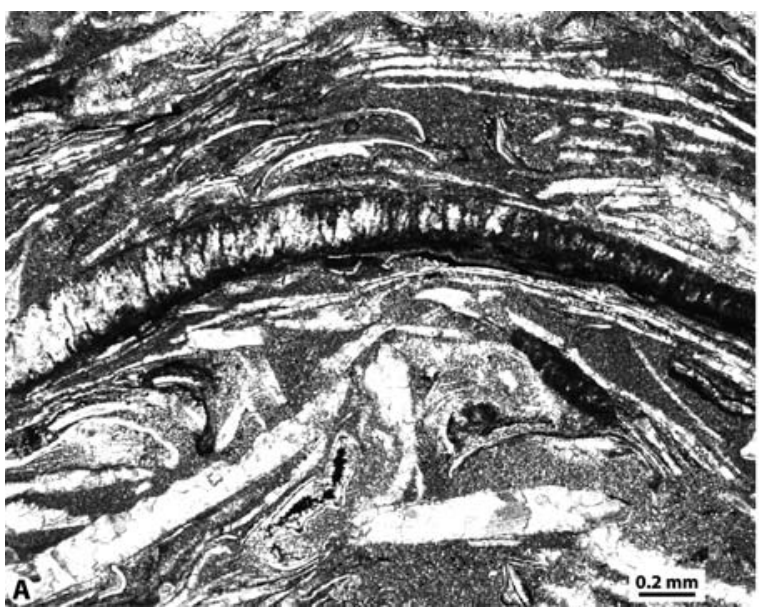

Fig. 4 Microboring in shells: partly micritized shells. The degree of micritization varies laterally within the same shell as in $\mathbf{A}$ and from the periphery to the inner part of the shell as in $\mathbf{B}$. Tubes

similarity between shells and peloids fits the petrographic observations. The difference is less obvious for $\mathrm{S}$ and $\mathrm{Mg}$ in one of the samples, whose distribution do not show distinct patterns.

\section{Interpretation}

In the studied samples, micritization of bivalve shells seems essential for the subsequent formation of peloids. During diagenesis, non-micritized shells tend to dissolve (Fig. 9A). Shells with a micritic envelope, however, form elongated clasts that are larger than the measured peloids (Fig. 9B). Shells that were previously entirely micritized appear to be the preferential source for the formation of type 1 peloids (Figs. 5, 8, and 12). Obviously, the micritization weakened the bivalve shells, facilitating their breakdown and abrasion (cf. Reid et al. 1992; Fig. 8). Compaction also plays an important role in the breakdown (Figs. 8 and 11).

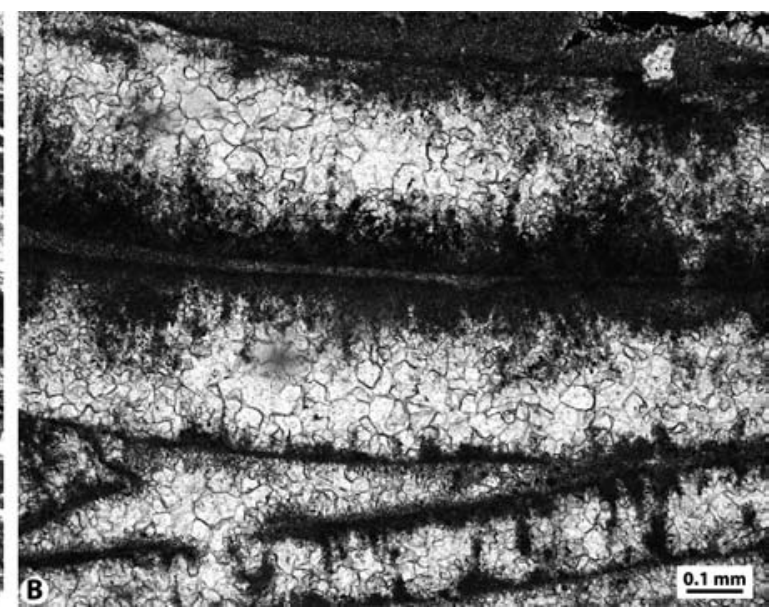

probably represent filled borings. Samples \#WO 18 in A and \#WO 32 in $\mathbf{B}$

Breakdown and particle-size reduction of skeletal grains evaluated in previous studies focused basically on boring activities by microorganisms (e.g., Swinchatt 1965; Stieglitz 1972) or syndepositional processes, such as water agitation (e.g., Chave 1960, 1964; Folk and Robles 1964; Swinchatt 1965). The process for shell-derived peloids reported here, rather mechanical and postdepositional, might have been underestimated in the interpretation of peloids, one of the most important components in carbonate depositional environments.

\section{Discussion and conclusion}

Fecal pellets, resulting from ejection by organisms (e.g., arthropods, mollusks, fishes) are among the bestdocumented examples of peloids. The origin is unambiguous because some of the features preserved within the peloids can distinctly be identified. Specifically, canals in transverse sections, when visible, can be linked to distinct 


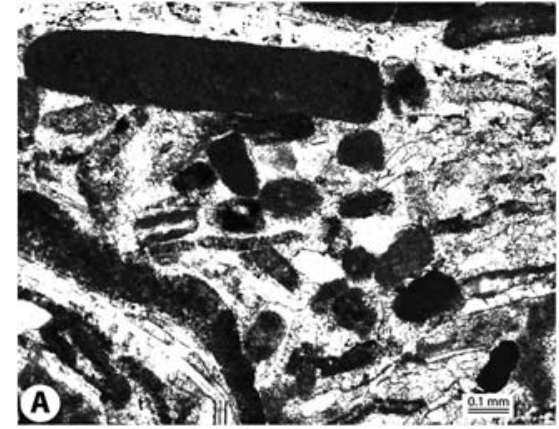

Fig. 5 (A) Overview of a peloid-rich sample. Sample \#WO 30. (B) Transitional stage in peloid formation. The proto-peloid (PP) in this stage is close enough to the bivalve shell $(\mathrm{Bi})$ from which it derived. Note the shell microstructures visible at high resolution (thin broken

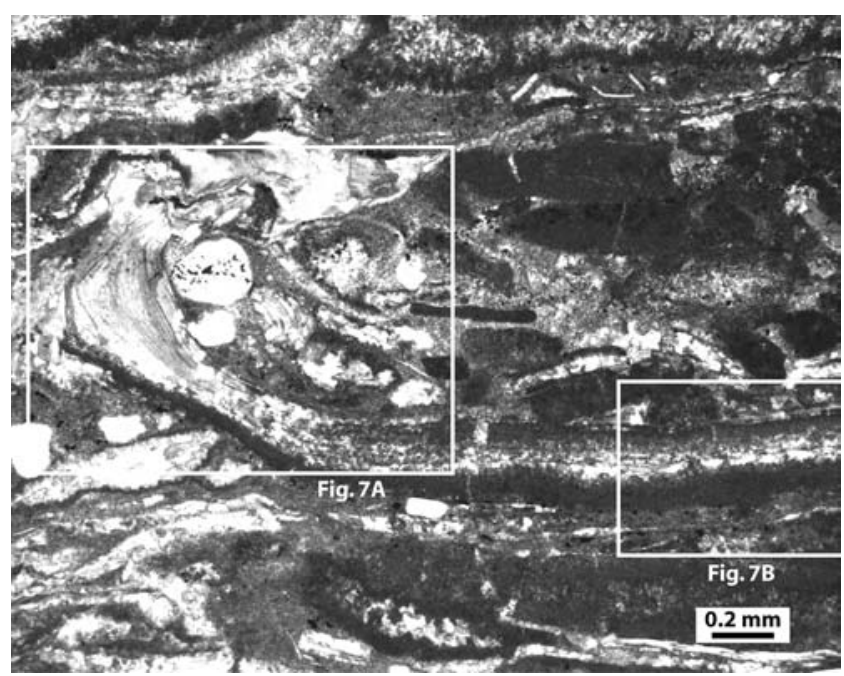

Fig. 6 Transition from well-preserved shell microstructures (detail in Fig. 7A) to partly preserved parts (detail in Fig. 7B). Sample \#WO 30

organisms (e.g., Favreina sp.). No such canals are visible in the Dorset material. Furthermore, the absence of organic matter and of opaque inclusions, and the lack of a peripheral rim around peloids, all characteristic to fecal pellets (e.g., Illing 1954; Purdy 1963a,b; Brown 1964), are supportive of a non-fecal origin.

Peloids may result from boring and rasping of mud by organisms, e.g., the boring sponge Cliona sp. (Fütterer 1974; Acker and Risk 1985), resulting in peloids assigned to bioerosional peloids. Macroscopic-scale bioerosion is not involved in the Dorset material, ruling out this mode for the formation of the peloids studied.

Microbial and precipitated peloids are widely associated with clotted textures and are commonly related to microbial activity. They are widely associated with reef facies (e.g., Sun and Wright 1989; Coniglio and James 1985; Chafetz 1986; Riding 2000). Similar peloids in the analyzed material are distinctly small and confined to a few shell cavities only, and, therefore, do not account for as an option to explain the abundance of peloids in the Dorset samples. Furthermore, precipitated peloids commonly have dentate
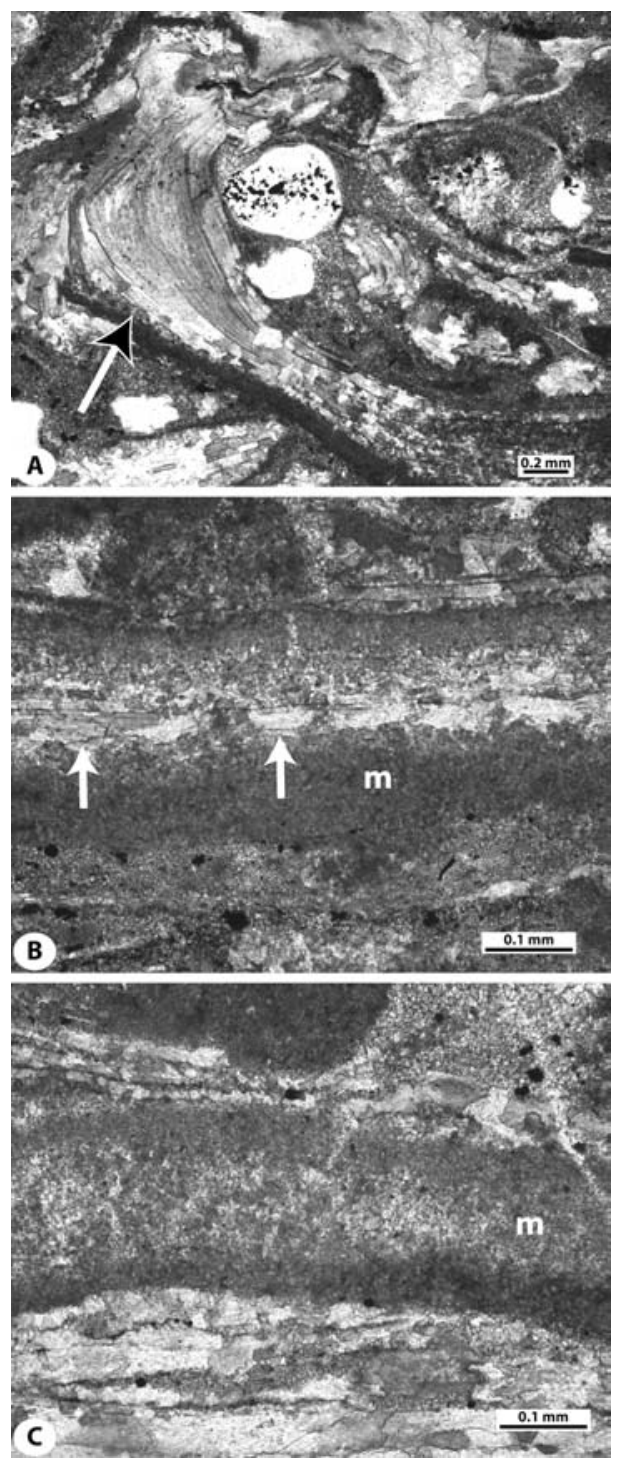

Fig. 7 Detailed photomicrographs from the same bivalve shell as in Fig. 6: (A) Well visible lamellar layer (arrow). (B) Transition with micritized peripheral shell part $(\mathrm{m})$ to relics of lamellar microstructures in the inner layer (arrows). (C) Entirely (but nonuniform) micritized (m) part of the shell. The picture was taken further to the right of the same shell as above, not seen in Fig. 6 


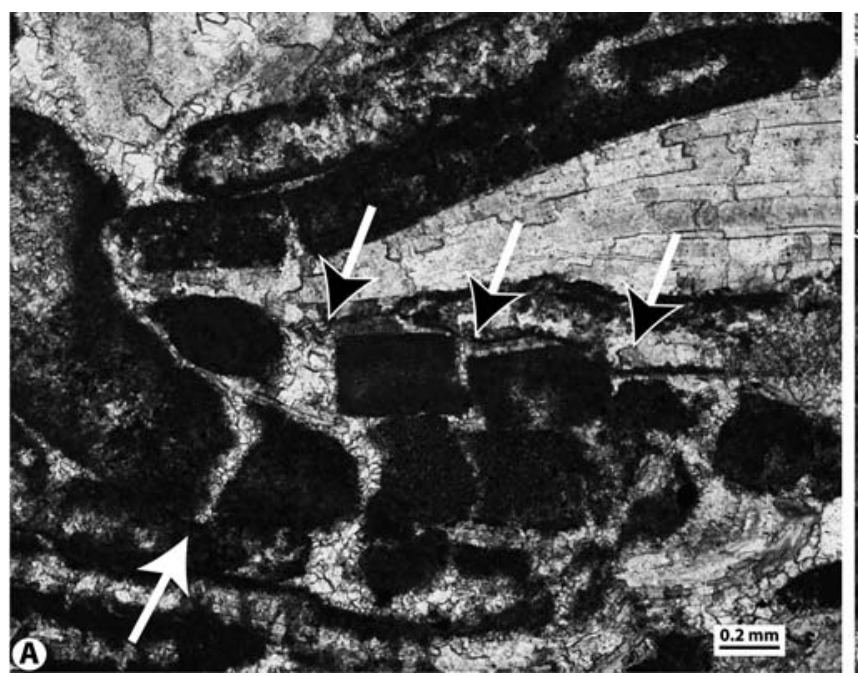

Fig. 8 (A) Breakdown of micritized shells, showing early and transitional stages in the formation of peloids (proto-peloids). The breakdown obviously resulted from mechanical overburden (black arrowheads). The source of the later peloids is close enough to be identified (white arrowhead). Sample \#WO 30. (B) Detail from a thin,

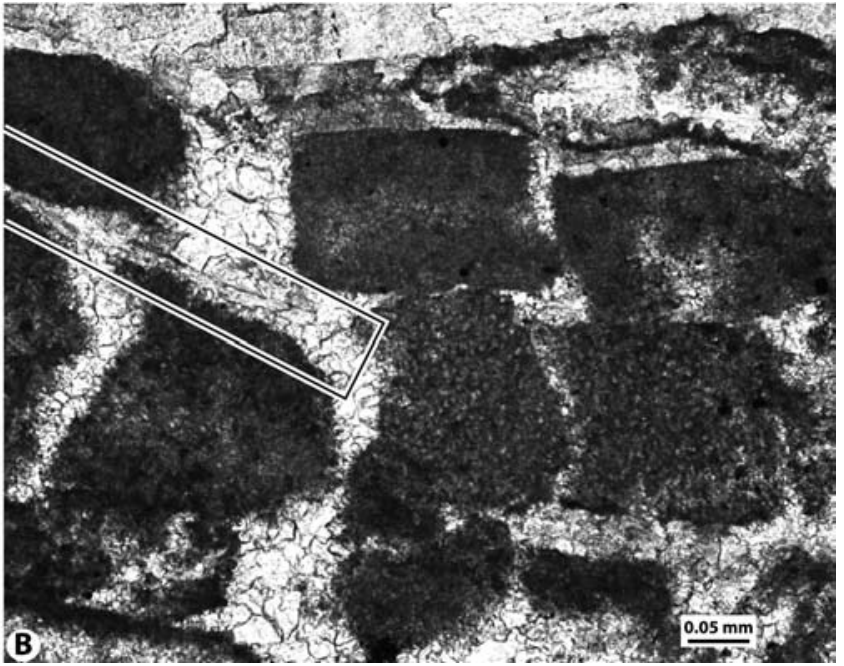

non-micritized peripheral layer (periostracum?) is preserved (rectangle), whereas the remnant of the shell is entirely micritized. In this example, the micritization process is thus stronger in the inner than in the peripheral layer
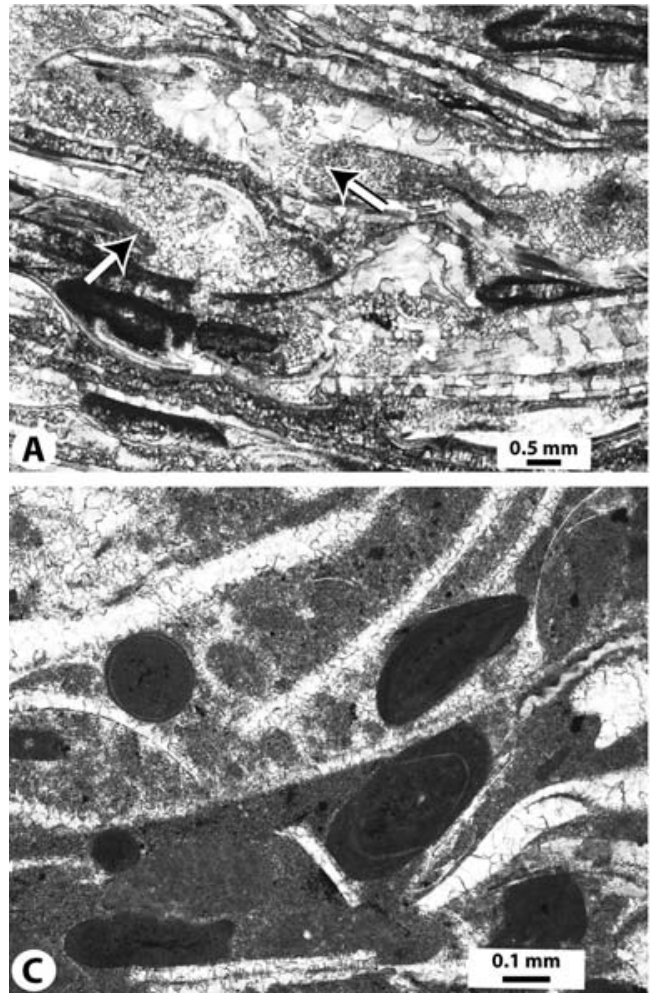

Fig. 9 (A) Non-micritized grains tend to dissolve, unlike the micritized shells illustrated above. Sample \#WO 18. (B) The breakdown of shells with micritic envelopes tends to result in the genesis of elongated grains that are longer than peloids (arrows). Sample \#WO 19. (C) Type 2 peloids include recognizable ostracodes, whose form they

or fuzzy rims around an initial center (Land and Goreau 1970; Macintyre 1977, 1985; Lighty 1985). Dentate rims, as described in previous studies, are not visible in the SEM images of peloids studied. Algal peloids result from the disintegration of calcified algae, deduced from internal fea-
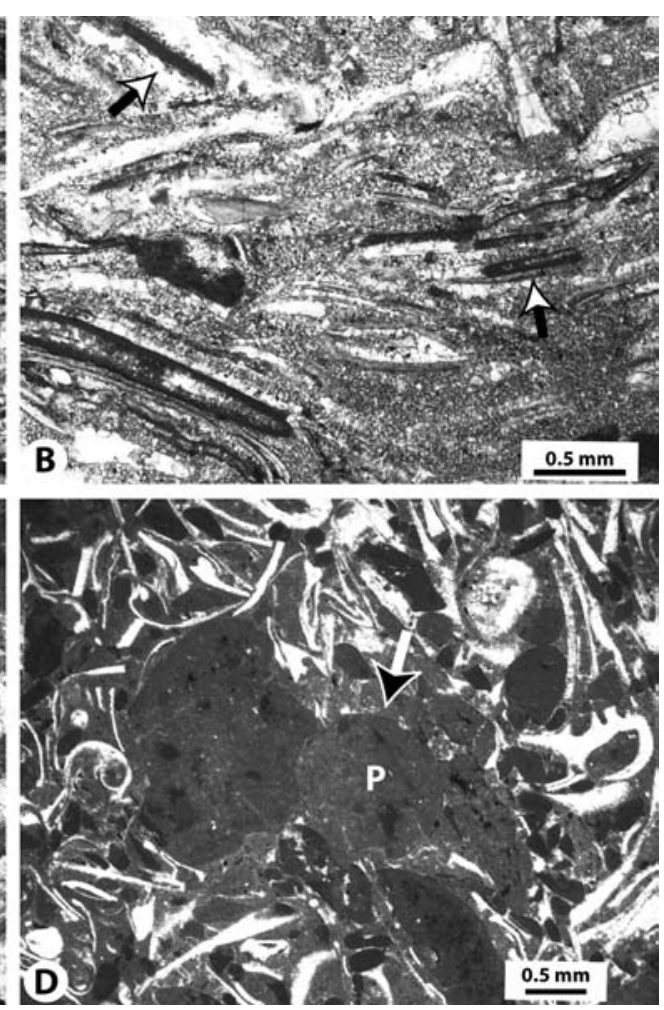

faithfully mimic. Sample \#DU 4. (D) The peloid type 3 (P) indicated by an arrow is close to the mud component from which it probably derived. Note the overall similarity between the muddy matrix and the resulting peloids (e.g., the small inclusions in both components). Sample \#DU 4

tures preserved in such peloids (Brown 1964; Wolf 1965; Wolf and Conolly 1965) and/or co-occurrence of peloids and algae (Coniglio and James 1985). Algae are absent in the material studied, making an algal origin for the peloids in the Dorset material unlikely. 

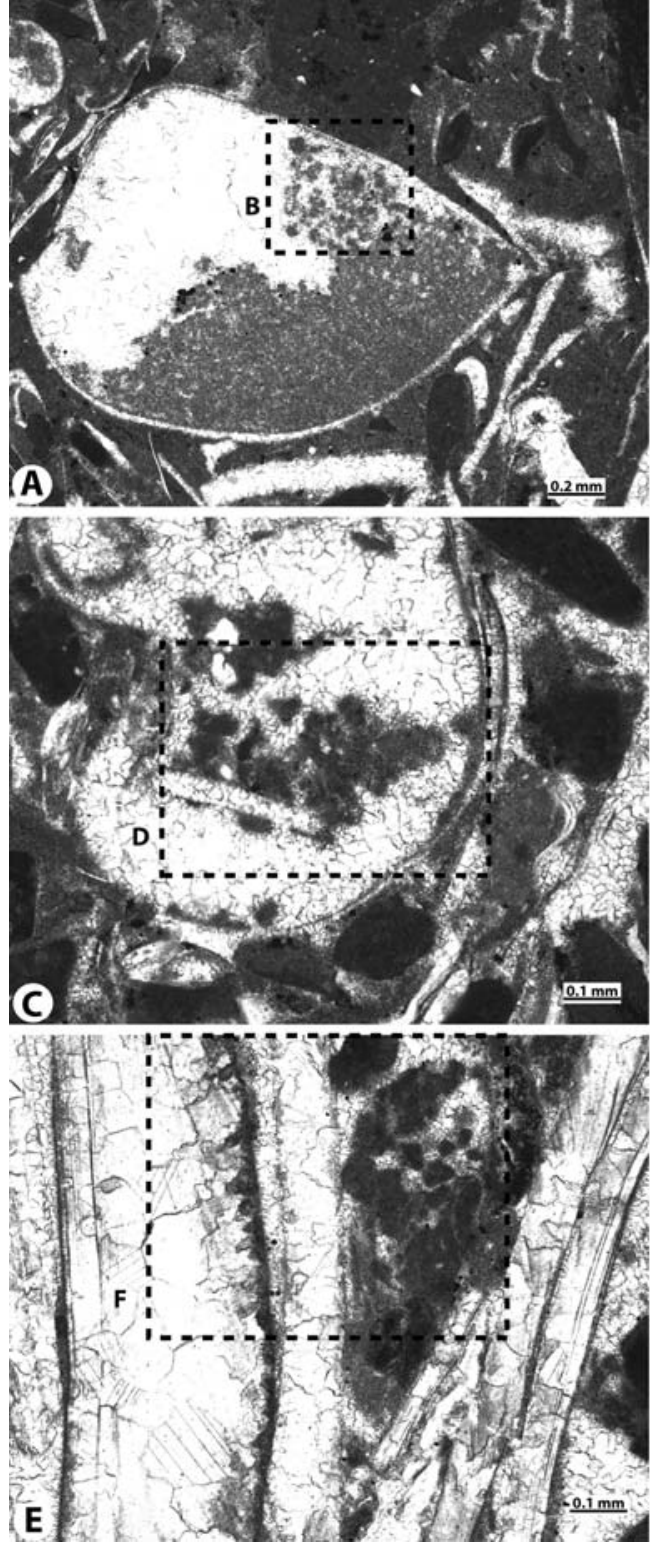

Fig. 10 Microbially induced peloids are confined to cavities, predominantly the intraparticle porosity of ostracodes (A-D) and, rarely, interparticle porosity of shells $(\mathbf{E}, \mathbf{F})$. Overall, these peloids are dis-

Carbonate mud can be reworked to the degree of forming mud grains or lithic peloids (e.g., Fahraeus et al. 1974). Mud peloids are similar to the micritic matrix that they are associated with (Fig. 8D). Lithic peloids and bivalve shell-derived peloids can be distinguished from each another in the Dorset material by the presence or absence of a muddy matrix.

Bahamite peloids are defined as resulting from micritization of grains, basically aggregate grains, ooids, and micritic intraclasts that they are commonly associated with (Beales 1958; Gygi 1969; Logan 1974). Bahamite peloids may appear close to the type 1 peloids of this study. However, the aforementioned grains are absent in the Dorset material, ruling out this possibility.
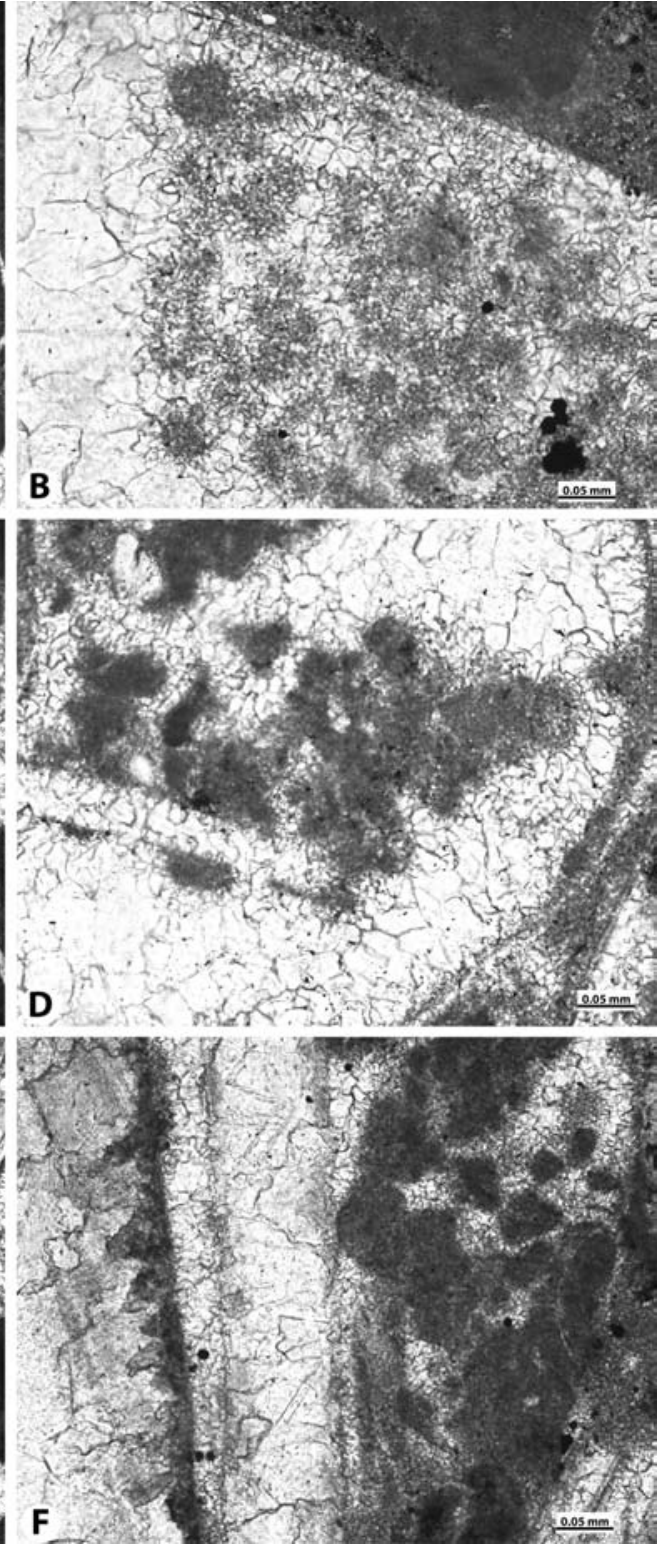

tinctly smaller than all other types described earlier and have diffuse contours (B, D, F, enlarged from $\mathbf{A}, \mathbf{C}, \mathbf{E}$, respectively)

If the genesis of peloids cannot be unequivocally proven, e.g., by observation of transitional forms, relics of algal features, or occurrence of aggregate grains in the host rock, a differentiation of peloid types cannot be made (Pusey 1975; cf. also Peterhänsel and Pratt 2001). Therefore, the origin of peloids should be interpreted with caution (Soudry and Nathan 1980) if one cannot undoubtedly reconstruct their source and the genetic pathway.

The possibility that peloids may result from alteration and breakdown of skeletal components was probably underestimated in past studies. The example described in the present paper emphasizes the importance of such processes in producing peloids. 

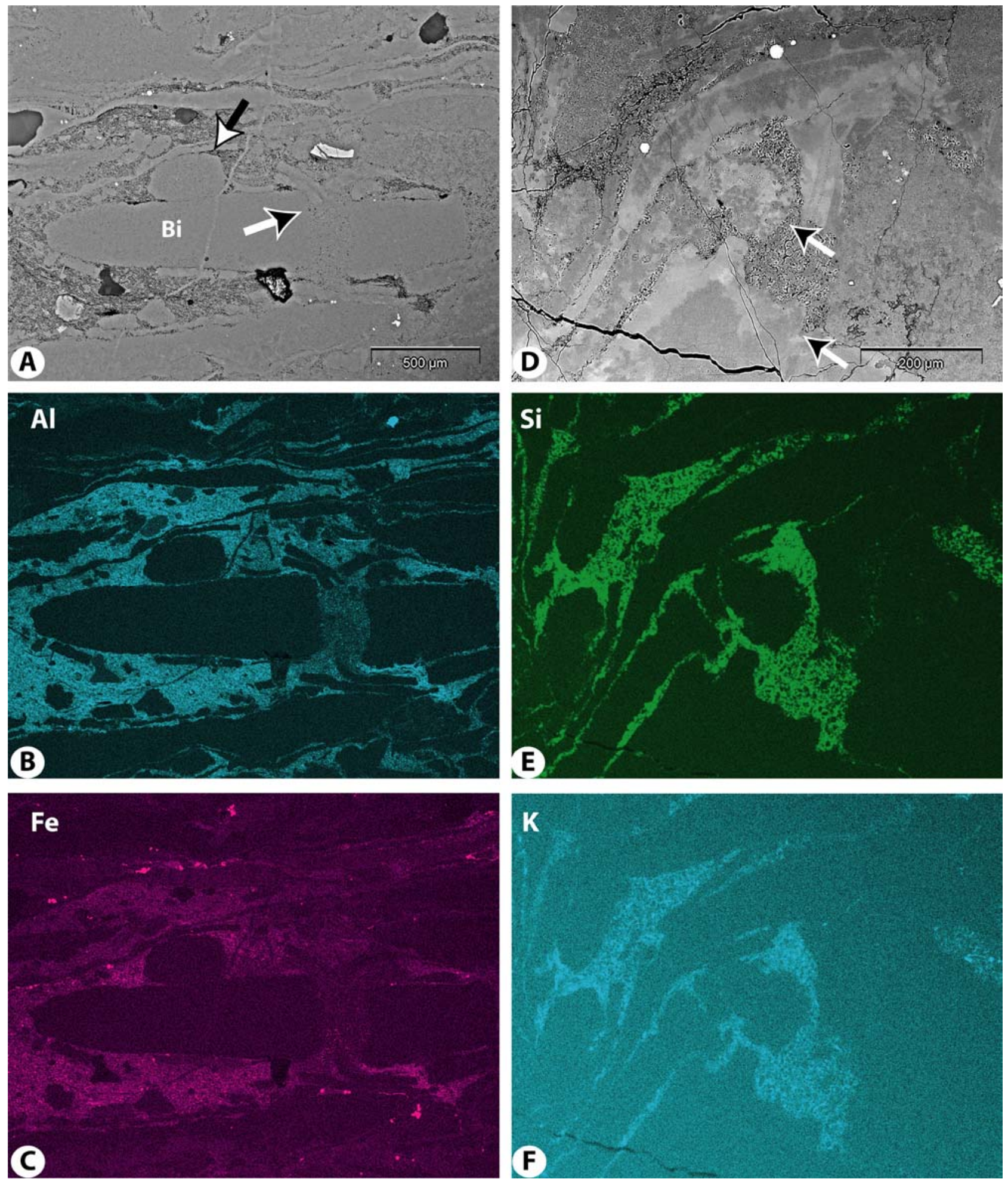

Fig. 11 (A) Rounded and isolated peloid (upper, white arrowhead). The breaking of a bivalve shell (Bi) probably resulted from overburden (lower, black arrowhead). (B) and (C) are EDS maps for Al and $\mathrm{Fe}$, respectively. (D) Proto-peloid (upper arrow), resulting from

disintegration of the bivalve shell (lower arrow). (E) and (F) are BSE maps for Si and K, respectively. Sample \#WO 30. A and D are SEM images in BSE mode, $\mathbf{B}, \mathbf{C}, \mathbf{E}$, and $\mathbf{F}$ are EDS maps 


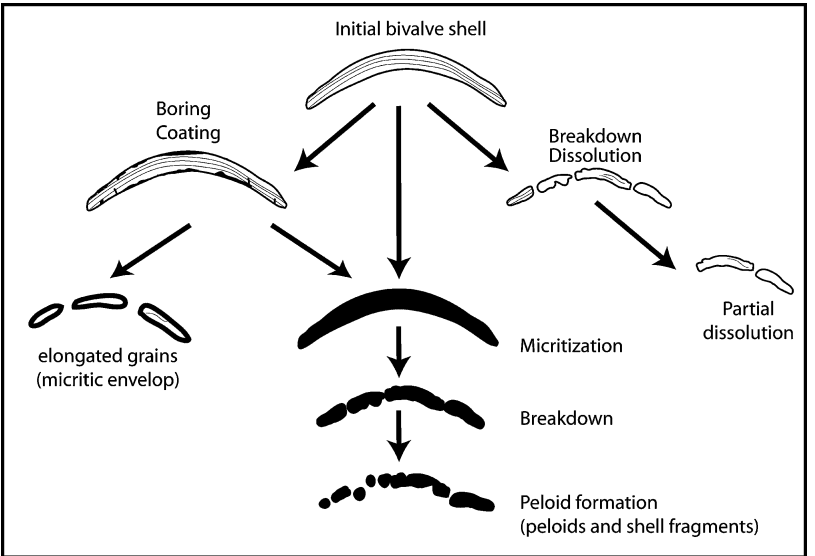

Fig. 12 Sketch illustrating the pathway of peloid formation derived from bivalve shells, as documented in the present study. Basically, three main pathways of shells are observed: dissolution, superficial boring and coating (micrite envelopes), leading to elongated grains larger than peloids, and complete micritization that leads to peloid formation with transitional stages of breakdown. Note that the breakdown is posterior to micritization

Acknowledgements We thank Ch. Neururer (Fribourg) for his help with the SEM and EDS analyses, and A. Freiwald and an anonymous referee for their thoughtful comments and suggestions. Funding by the Swiss National Science Foundation (Project No. 20-67736.02) and the University of Fribourg is gratefully acknowledged.

\section{References}

Acker KL, Risk MJ (1985) Substrate destruction and sediment production by the boring sponge Cliona caribbaea on Grand Cayman Island. J Sediment Petrol 55:705-711

Anderson FW (1985) Ostracod faunas in the Purbeck and Wealden of England. J Micropalaeont 4:1-68

Bathurst RGC (1966) Boring algae, micrite envelopes and lithification of molluscan biosparites. Geol J 5:15-32

Bathurst RGC (1975) Carbonate sediments and their diagenesis. Dev Sedimentol 12:620

Beales FW (1958) Ancient sediments of Bahaman type. AAPG Bull 42:1845-1880

Brown PR (1964) Petrography and origin of some Upper Jurassic beds from Dorset, England. J Sediment Petrol 34:254-269

Chafetz HS (1986) Marine peloids: a product of bacterially induced precipitation of calcite. J Sediment Petrol 56:812-817

Chave KE (1960) Carbonate skeletons to limestones-problems. Trans N Y Acad Sci 23(Ser 2):14-24

Chave KE (1964) Skeletal durability and preservation. In: Imbrie J, Newell N (eds) Approaches to paleoecology. John Wiley and Sons, New York, pp 377-387

Clements RG (1993) Type-section of the Purbeck Limestone Group, Durlston Bay, Swanage, Dorset. Proc Dorset Nat Hist Archeol Soc 114:181-206

Coniglio M, James NP (1985) Calcified algae as sediment contributors to early Paleozoic limestones: evidence from deep-water sediments of the Cow Head Group, western Newfoundland. J Sediment Petrol 55:746-754

Ensom PC (1985) An annotated section of the Purbeck Limestone Formation at Worbarrow Tout, Dorset. Proc Dorset Nat Hist Archeol Soc 106:87-91

Fahraeus LE, Slatt RM, Nowlan GS (1974) Origin of carbonate pseudopellets. J Sediment Petrol 44:27-29

Flügel E (1982) Microfacies analysis of limestones. Springer, Heidelberg Berlin New York, 633 pp

Flügel E (2004) Microfacies of carbonate rocks: analysis, interpretation and application. Springer, Heidelberg Berlin New York, $976 \mathrm{pp}$
Folk RL, Robles R (1964) Carbonate sands of Isla Perez, Alacran reef complex, Yucatan. J Geol 72:255-292

Fütterer DK (1974) Significance of the boring sponge Cliona for the origin of fine-grained material of carbonate sediments. J Sediment Petrol 44:79-84

Gygi RA (1969) Zur Stratigraphie der Oxford-Stufe (oberes JuraSystem) der Nordschweiz und des süddeutschen Grenzgebietes. Beitr Geol Karte Schweiz NF 136:123 pp

Illing LV (1954) Bahaman calcareous sands. AAPG Bull 38:1-95

Land LS, Goreau TF (1970) Submarine lithification of Jamaican reefs. J Sediment Petrol 40:457-462

Lighty RG (1985) Preservation of internal reef porosity and diagenetic sealing of submerged early Holocene barrier reef, southeast Florida shelf. SEPM Spec Publ 36:123-151

Logan BW (1974) Inventory of diagenesis in Holocene-Recent carbonate sediments, Shark Bay, Western Australia. In: Logan BW, Read JF, Hagan GM, Hoffman P, Brown RG, Woods PJ, Gebelein CD (eds) Evolution and diagenesis of Quaternary carbonate sequences, Shark Bay, Western Australia, AAPG Memoir, 22, pp 195-249

Macintyre IG (1977) Distribution of submarine cements in a modern Caribbean fringing reef, Galeta Point, Panama. J Sediment Petrol 47:503-516

Macintyre IG (1985) Submarine cements-the peloidal question. SEPM Spec Publ 36:109-116

Maliva RG, Dickson JAD (1992) The mechanism of skeletal aragonite neomorphism: evidence from neomorphosed mollusks from the upper Purbeck Formation (Late Jurassic-Early Cretaceous), southern England. Sediment Geol 76:221-232

McKee ED, Gutschick RC (1969) History of the Redwall Limestone of Northern Arizona. Geol Soc Am Mem 114:726

Milner AR, Batten DJ (2002) Life and environments in Purbeck times. Spec Pap Palaeont 68:268

Norris G (1985) Palynology and British Purbeck facies. Geol Mag 122:187-190

Peterhänsel A, Pratt BR (2001) Nutrient-triggered bioerosion on a giant carbonate platform masking the postextinction Famennian benthic community. Geology 29:1079-1082

Purdy EG (1963a) Recent calcium carbonate facies of the Great Bahama Bank. 2. Sedimentary facies. J Geol 71:472-497

Purdy EG (1963b) Recent calcium carbonate facies of the Great Bahama Bank. 1. Petrography and reaction groups. J Geol 71:334-355

Pusey WC III (1975) Holocene carbonate sedimentation on northern Belize shelf. In: Wantland KF, Pusey WC III (eds) Belize Shelf-carbonate sediments, clastic sediments, and ecology,AAPG Studies in Geology, 2. pp 131-233

Reid RP, Macintyre IG, Post JE (1992) Micritized skeletal grains in northern Belize lagoon: a major source of $\mathrm{Mg}$-calcite mud. J Sediment Petrol 62:145-156

Riding R (2000) Microbial carbonates: the geological record of calcified bacterial-algal mats and biofilms. Sedimentology 47:179-214

Scholle PA, Ulmer-Scholle DS (2003) A color guide to the petrography of carbonate rocks. AAPG Memoir, 77, $474 \mathrm{pp}$

Soudry D, Nathan Y (1980) Phosphate peloids from the Negev phosphorites. J Geol Soc Lond 137:749-755

Stieglitz RD (1972) Scanning electron microscopy of the fine fraction of Recent carbonate sediments from Bimini, Bahamas. J Sediment Petrol 42:211-226

Sun SQ, Wright VP (1989) Peloidal fabrics in Upper Jurassic reefal limestones, Weald Basin, southern England. Sediment Geol 65:165-181

Swinchatt JP (1965) Significance of constituent composition, texture, and skeletal breakdown in some Recent carbonate sediments. J Sediment Petrol 35:71-90

Wilson RCL (1965) Dual classification for point-counting limestones. Nature 207:849-850

Wolf KH (1965) Grain-diminution of algal colonies to micrite. J Sediment Petrol 35:420-427

Wolf KH, Conolly JR (1965) Petrogenesis and paleoenvironment of limestone lenses in upper Devonian red beds of New South Wales. Palaeogeogr Palaeoclimatol Palaeoecol 1:69-111 